\title{
Characterization of bacteriocin-like inhibitory substances (BLIS) from sourdough lactic acid bacteria and evaluation of their in vitro and in situ activity
}

\author{
A. Corsetti ${ }^{1}$, L. Settanni ${ }^{1,2}$ and D. Van Sinderen ${ }^{2}$ \\ ${ }^{1}$ Dipartimento di Scienze degli Alimenti, Sezione di Tecnologie e Biotecnologie degli Alimenti, Università degli Studi di Perugia, Perugia, \\ Italy, and ${ }^{2}$ Department of Microbiology, University College Cork, Cork, Ireland
}

2003/0809: received 11 September 2003, revised and accepted 30 October 2003

\section{ABSTRACT}

A. CORSETTI, L. SETTANNI AND D. VAN SINDEREN. 2004.

Aims: To identify and characterize bacteriocion-producing lactic acid bacteria (LAB) in sourdoughs and to compare in vitro and in situ bacteriocin activity of sourdough- and nonsourdough LAB.

Methods and Results: Production of antimicrobial compounds by 437 Lactobacillus strains isolated from 70 sourdoughs was investigated. Five strains (Lactobacillus pentosus 2MF8 and 8CF, Lb. plantarum 4DE and 3DM and Lactobacillus spp. CS1) were found to produce distinct bacteriocin-like inhibitory substances (BLIS). BLISproducing Lactococcus lactis isolated from raw barley showed a wider inhibitory spectrum than sourdough LAB, but they did not inhibit all strains of the key sourdough bacterium Lb. sanfranciscensis. Antimicrobial production by Lb. pentosus $2 \mathrm{MF} 8$ and Lc. lactis M30 was also demonstrated in situ.

Conclusions: BLIS production by sourdough LAB appears to occur at a low frequency, showing limited inhibitory spectrum when compared with BLIS-producing Lc. lactis. Nevertheless, they are active BLIS producers under sourdough and bread-making conditions.

Significance and Impact of the Study: The activity of BLIS has been demonstrated in situ. It may influence the complex sourdough microflora and support the implantation and stability of selected insensitive bacteria, such as Lb. sanfranciscensis, useful to confer good characteristics to the dough.

Keywords: bacteriocins, BLIS, Lactobacillus pentosus, Lactobacillus sanfranciscensis, Lactococcus lactis, sourdough.

\section{INTRODUCTION}

Lactic acid bacteria (LAB) occur naturally in several raw materials (e.g. milk, meat, flour, etc.) used to produce foods (Rodríguez et al. 2000). LAB are used as 'natural' or 'selected' starters in food fermentations in which they perform both acidification, due to the production of lactic and acetic acids, flavour-compound production, as well as protection of the food from spoilage and pathogenic microorganisms by producing organic acids, hydrogen peroxide, diacetyl (Atrih et al. 2001; Messens and De Vuyst 2002), antifungal compounds such as fatty acids (Corsetti et al.

Correspondence to: A. Corsetti, Dipartimento di Scienze degli Alimenti, Sezione di Tecnologie e Biotecnologie degli Alimenti, Universita degli Studi di Perugia,

Via S. Costanzo-06126Perugia, Italy (e-mail: corsetti@unipg.it).
1998) or phenyllactic acid (Lavermicocca et al. 2000), and/ or bacteriocins (De Vuyst and Vandamme 1994a).

Bacteriocins are antimicrobial peptides or small proteins which inhibit, by a bactericidal or bacteriostatic mode of action, micro-organisms that are usually closely related to the producer strain (De Vuyst and Vandamme 1994b; Schillinger and Holzapfel 1996). A bacteriocin producer protects itself against its own antimicrobial compound by means of a system referred as immunity, which is expressed concomitantly with the antimicrobial peptide (Nes et al. 1996). Bacteriocins from LAB have been classified, initially by Klaenhammer (1993), in four classes on the basis of common, mainly structural, characteristics. In a later review, Nes et al. (1996) restricted the LAB-produced bacteriocins to three classes because the existence of a fourth class as 
proposed by Klaenhammer (1993), i.e. complex compounds needing a carbohydrate or lipid moiety for activity, had been based on unpurified, and therefore ill-defined, compounds. Class I are small, heat-stable peptides containing thioether amino acids, like lanthionine, and are for this reason named lantibiotics. Class II are small, hydrophobic, heat-stable, nonmodified bacteriocins consisting of either a single peptide with antilisterial activity (class IIa) or two polypeptide chains (class IIb), and also include other peptide bacteriocins (class IIc). Class III consist of large, hydrophilic, heat-labile proteins (Klaenhammer 1993; Vaughan et al. 2001; Eijsink et al. 2002; Messens and De Vuyst 2002). Even if chemical, enzymatic or physical characteristics of the food, food processing, or the physiological state of the bacteriocinproducing micro-organism can limit the bacteriocin activity in situ (Eckner 1992; Messens and De Vuyst 2002), it has been claimed that micro-organisms producing bacteriocins possess a competitive advantage over other organisms living in the same natural environment (Vaughan et al. 2001).

Sourdoughs are considered extremely complex ecosystems where $\mathrm{LAB}$ and yeasts represent the prevailing microflora (Corsetti et al. 1996). In this system the synthesis of bacteriocins and other antimicrobial molecules could regulate the complex interactions within the starter microorganisms and between the starter and the contaminant microflora of the sourdough (Corsetti et al. 1996; Hammes and Gänzle 1997). It has been reported that if sourdoughs undergo considerable propagation, this will lead to the emergence of one or two species, which prevail at three or four orders of magnitude above the contaminating microflora (Hammes et al. 1996; Hammes and Gänzle 1997).

In this context, besides particular adaptative responses to the conditions prevailing during sourdough fermentation (e.g. preferred utilization of maltose, the more available fermentable flour carbohydrate, high efficiency in the co-metabolism of maltose or glucose with various substrates) (Gobbetti and Corsetti 1997), the production of bacteriocins by sourdough LAB could provide another selective advantage for the producer strains (Hammes and Gänzle 1997). Some nonorganic acid inhibitory substances have been so far discovered from sourdough LAB and include the bacteriocins bavaricin A (Larsen et al. 1993), plantaricin ST31 (Todorov et al. 1999), the bacteriocin-like inhibitory substance (BLIS) C57 (Corsetti et al. 1996) and the small molecular weight antibiotic reutericyclin (Gänzle et al. 2000). Nevertheless, the role of bacteriocins under conditions that truly reflect sourdough fermentation remains to be determined, while the effective use of bacteriocins or bacteriocin-producing LAB in sourdough production and leavened baked product preservation relies on the isolation and characterization of bacteriocins from sourdough-adapted LAB, and on the understanding of the activity of these antimicrobial substances in the natural chemical-physical conditions of sourdough fermentation (Messens and De Vuyst 2002). Moreover, new bacteriocins could be discovered with activity against cereal-associated and spoilage or, eventually, pathogenic micro-organisms. In the latter case, the possible use of bacteriocins in association with other preservatives for controlling food spoilage micro-organisms could reduce the concentration of 'non-natural' preservatives, thus meeting the consumer's wishes for minimally processed foods (Rasch and Knochel 1998).

The aim of this study was to: (i) evaluate the presence of bacteriocion-producing LAB isolated from a large number of sourdoughs used in bread-making at artisanal and industrial level, (ii) characterize the bacteriocins for their inhibitory spectrum and for their in vitro and in situ (during sourdough fermentation) activity, (iii) compare the in vitro and in situ bacteriocin activity of sourdough- and nonsourdough-isolated LAB.

\section{MATERIALS AND METHODS}

\section{Sourdough samples and isolation and identification of LAB}

Eighteen wheat sourdoughs were collected from artisanal and industrial bakeries of central Italy (Marche, Toscana and Lazio regions). Three rye sourdoughs were obtained from a semi-industrial bakery from Germany. Isolation and identification of LAB from sourdoughs were performed as previously described (Corsetti et al. 2001).

\section{Strains and growth conditions}

Lactobacillus sanfranciscensis (85 strains), Lb. plantarum (34 strains), Lb. alimentarius (33 strains), Lb. brevis (30 strains), $L b$. farciminis (13 strains), $L b$. fructivorans (nine strains), $L b$. fermentum (five strains), Lb. hilgardii (three strains), $L b$. pentosus (two strains), Lb. pontis (two strains), and 221 unidentified Lactobacillus strains isolated from 70 wheat and rye sourdoughs (Gobbetti et al. 1994; Corsetti et al. 2001; this paper), forming a total of 437 strains, were screened for bacteriocin production. Lactobacillus sanfranciscensis strains were cultured in sourdough bacteria (SDB) broth (Kline and Sugihara 1971 ) at $30^{\circ} \mathrm{C}$ for approx. $18 \mathrm{~h}$ prior to use. All other lactobacilli were cultivated in modified-MRS (mMRS) (maltose and fresh yeast extract were added at final concentrations of 1 and $10 \%$, respectively, and the final $\mathrm{pH}$ was adjusted to $5 \cdot 6$ ) at $30^{\circ} \mathrm{C}$ for approx. $18 \mathrm{~h}$. Two bacteriocinproducing strains of Lactococcus lactis belonging to the National Food Biotechnology Centre (NFBC) culture collection (University College Cork, Ireland), were included in this study in order to compare their inhibitory activity with that of sourdough LAB. A nonbacteriocin-producing strain of Lc. lactis (strain Q13) isolated from sourdough was used as 
negative control. Lactococci were cultured in M17 (Difco Laboratories, Detroit, MI, USA) broth at $30^{\circ} \mathrm{C}$ for $24 \mathrm{~h}$. The indicator strains, listed in Table 1, were propagated as follows: lactobacilli in SDB or in MRS (De Man et al. 1960) at $30^{\circ} \mathrm{C}$ for $24 \mathrm{~h}$ except for $L b$. sakei, for which a mMRS was used, and $L b$. delbrueckii ssp. bulgaricus, incubated at $37^{\circ} \mathrm{C}$; Streptococcus thermophilus in M17 (Difco) at $37^{\circ} \mathrm{C}$ for $24 \mathrm{~h}$; Listeria innocua in TSBYE (Tryptone Soy Broth supplemented with $0.6 \%(\mathrm{w} / \mathrm{v})$ yeast extract) (Difco) at $30^{\circ} \mathrm{C}$ for $24 \mathrm{~h}$; Bacillus strains in BN (Difco) at $30^{\circ} \mathrm{C}$ for $24 \mathrm{~h}$; and yeasts in Wallerstein $\mathrm{Lab}$ (WL) (Difco) at $30^{\circ} \mathrm{C}$ for $24 \mathrm{~h}$. The indicator strains $\mathrm{Lb}$. sakei LMG 2313 (obtained from the Laboratory of Microbial Gene Technology, Ås, Norway) and L. innocua 4202 belonged to the culture collection of the NFBC; all other strains were obtained from the culture collection of the Department of Food Science, Section of Food Technology and Biotechnology, Laboratory of Microbiology (University of Perugia, Italy). With the exception of DSM and ATCC strains, and of $L b$. sakei, $L b$. casei ssp. pseudoplantarum, $L b$. casei subsp. casei, Lb. curvatus, L. innocua, S. thermophilus, and Bacillus spp. all other strain used as indicators, listed in Table 1, were previously isolated from sourdoughs (Gobbetti et al. 1994; Corsetti et al. 1998, 2001).

\section{Assays for bacteriocin activity}

The antimicrobial activity of lactobacilli was detected by two methods, the agar-spot deferred test and the well diffusion assay (Schillinger and Lücke 1989). In the first case, colonies of the strains to be tested for bacteriocin production were grown on the surface of SDB or mMRS containing $1.5 \%$ agar for $24 \mathrm{~h}$ at $30^{\circ} \mathrm{C}$. The indicator strains Lb. farciminis CC10, Lb. sakei LMG 2313, L. innocua 4202 and $L b$. delbrueckii subsp. bulgaricus B397, were inoculated (4\% v/v) into $7 \mathrm{ml}$ of soft agar medium (containing $0.7 \%$ agar) specific for each strain, at a final cellular concentration of $1.5 \times 10^{5} \mathrm{CFU} \mathrm{ml}{ }^{-1}$. The soft media were poured on the plate where growth of the producers occurred and the plates were incubated anaerobically, at the optimal growth temperature for the indicator strains, for $24 \mathrm{~h}$. Inhibition was scored positive in presence of a detectable clearing zone around the colony of the producer strain.

For the well diffusion assay, agar base medium $(1.5 \%$ agar) was overlaid with soft agar medium containing the indicator strain, as reported above. Thereafter wells $(10 \mathrm{~mm}$ in diameter) were cut into the agar and 2001 of the cell-free supernatant of the potential producer strains was placed into each well. In order to eliminate the inhibitory effect of lactic acid and/or $\mathrm{H}_{2} \mathrm{O}_{2}$, the supernatants were adjusted to $\mathrm{pH} 6 \cdot 5$ with $1 \mathrm{~mol} \mathrm{l}^{-1} \mathrm{NaOH}$ and treated with catalase $\left(1 \mathrm{mg} \mathrm{ml} l^{-1}\right)$, followed by filtration through a $0 \cdot 22-\mu \mathrm{m}$ pore size filter (Nucleopore, Costar Corporation, Cambridge, MA, USA). Prior to incubation for $24 \mathrm{~h}$ at the optimal growth temperature for the indicator strains, plates were refrigerated $\left(4^{\circ} \mathrm{C}\right)$ for $4 \mathrm{~h}$ to allow the radial diffusion of the compounds contained in the supernatant.

The antibacterial activity of the supernatants was evaluated by the critical dilution assay of Barefoot and Klaenhammer (1983). Bacteriocin activity was defined as the reciprocal of the highest dilution showing definite inhibition of the indicator strains and was expressed as activity units per millilitre $\left(\mathrm{AU} \mathrm{m} \mathrm{l}^{-1}\right)$.

\section{Phenotypic and genotypic identification of lactobacilli}

Unidentified Gram-positive and catalase-negative rods showing positive results after the well diffusion assay were subjected to phenotypic identification by API 50 CHL System (bioMérieux, Lyon, France). The API test was preceded by assays, which considered growth at 15 and $45^{\circ} \mathrm{C}, \mathrm{CO}_{2}$ production from glucose, $\mathrm{NH}_{3}$ production from arginine and esculine hydrolysis.

All bacteriocin-producer strains were also identified by $16 \mathrm{~S}$ rDNA sequencing. Genomic DNA of the isolates was extracted from $2 \mathrm{ml}$ of overnight cultures grown in MRS by the method of De Los Reyes-Gavilàn et al. (1992). Primers (MWG Biotech AG, Ebersberg, Germany), designed from conserved sequences within bacterial $16 \mathrm{~S}$ rRNA region, were LacbF 5'-TGCCTAATACATGCAAGT-3' and LacbR 5'-CTTGTTACGACTTCACCC-3' derived from the homologous regions of several 16S rRNA sequences of Lactobacillus species, and corresponding to positions 38 to 55 , and 1503 to 1520 , respectively, of $16 \mathrm{~S}$ rRNA region from Lb. brevis (accession no. AF515220).

PCR was carried out using Taq PCR Master Mix Kit (Qiagen, Hilden, Germany). The $50 \mu \mathrm{l}$ PCR mixtures contained $25 \mu \mathrm{l}$ of Taq PCR Master Mix, 2 pmol of each primer, $2 \mu \mathrm{l}$ of template DNA ( $c a 50 \mathrm{ng}$ of DNA) and sterile distilled $\mathrm{H}_{2} \mathrm{O}$. PCR amplification of the $16 \mathrm{~S}$ rDNA was performed using the Primus PCR System (MWG Biotech AG). The PCR program comprised an initial template denaturation step for $2 \mathrm{~min}$ at $94^{\circ} \mathrm{C}$ followed by 30 cycles of denaturation for $30 \mathrm{~s}$ at $94^{\circ} \mathrm{C}$, annealing for $1 \mathrm{~min}$ at $49^{\circ} \mathrm{C}$ and extension for $1 \mathrm{~min}$ at $72^{\circ} \mathrm{C}$. The final extension step was for 7 min at $72^{\circ} \mathrm{C}$.

The PCR products were purified by the ConcertTM Rapid PCR Purification System (Gibco BRL, Cergy Pontoise, France). DNA sequencing reactions were performed by MWG Biotech AG.

\section{Effect of enzymes and heat treatment on the antimicrobial activity}

Sensitivity to proteolytic enzymes of each supernatant containing antimicrobial activity was tested by treatment 
Table 1 Inhibitory activity of sourdough lactobacilli determined by well diffusion assay

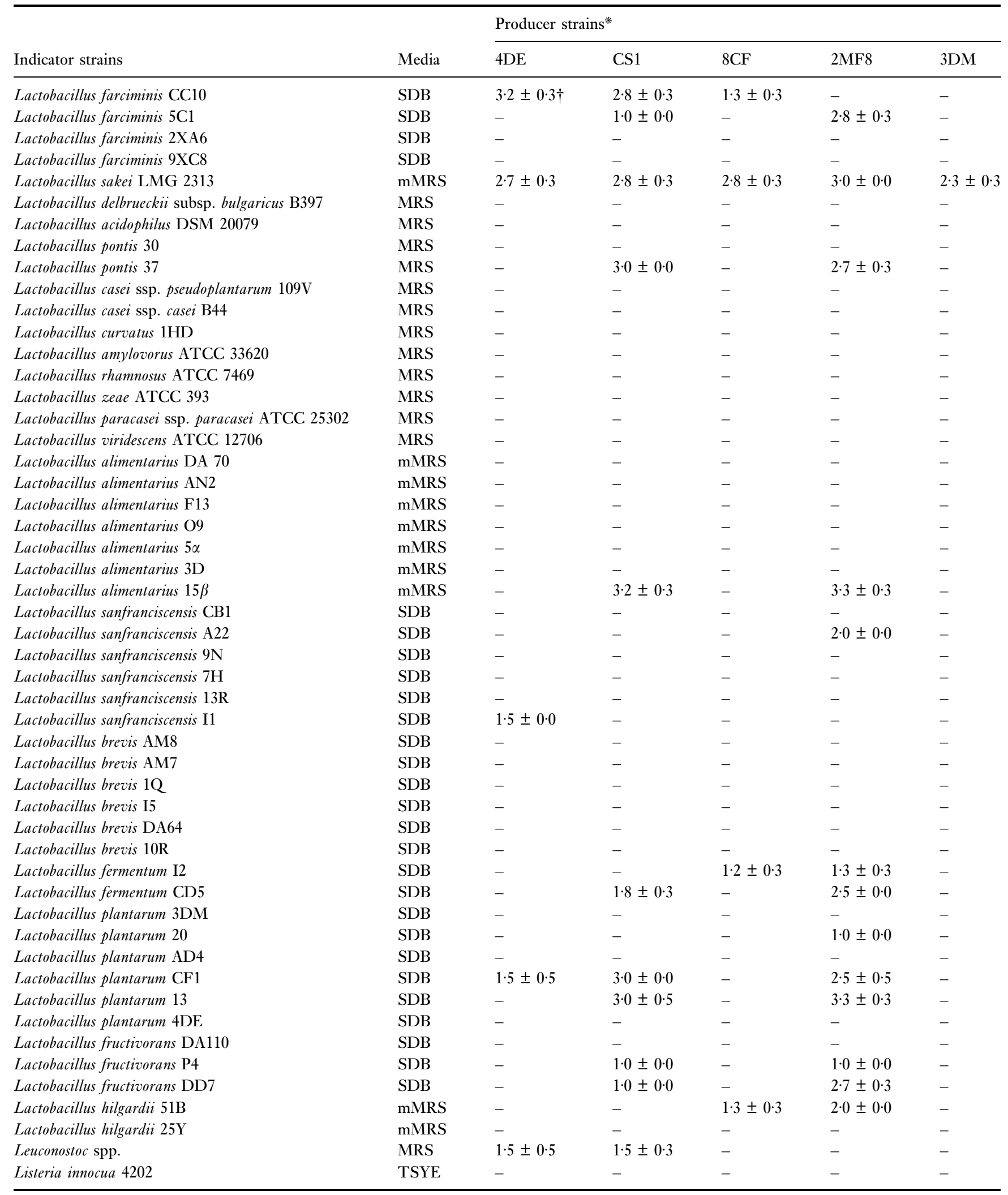




\begin{tabular}{llllll}
\hline & & \multicolumn{2}{l}{ Producer strains* } & & \\
\cline { 3 - 5 } Indicator strains & & 4DE & CS1 & 8CF & 2MF8 \\
\hline Streptococcus thermophilus X6 & Media & & & - \\
Weissella confusa DSM 20196 & MRS & - & - & - & - \\
Bacillus cereus 660 & BN & - & - & - & - \\
Bacillus subtilis 813 & BN & - & - & - & - \\
Saccharomyces cerevisiae 141 & WL & - & - & - & - \\
Saccharomyces exiguus M14 & WL & - & - & - \\
\hline
\end{tabular}

*Producer strains are termed by the collection reference abbreviation: 4DE, Lb. plantarum; CS1, Lactobacillus spp.; 8CF and 2MF8, Lb. pentosus; 3DM, Lb. plantarum.

$\dagger$ Width of the inhibition zone $(\mathrm{mm})$.

'-', No inhibition zone. Results indicate mean \pm S.D. of three independent experiments.

with proteinase $\mathrm{K}\left(12.5 \mathrm{U} \mathrm{mg}^{-1}\right)$, protease $\mathrm{B}\left(45 \mathrm{U} \mathrm{mg}^{-1}\right)$ and trypsin $\left(10.6 \mathrm{U} \mathrm{mg}^{-1}\right)$ at a final concentration of $1 \mathrm{mg} \mathrm{ml}{ }^{-1}$ in phosphate buffer $(\mathrm{pH} \mathrm{7 \cdot 0)}$. The supernatants were examined for the sensitivity to lipolityc and amylolityc enzymes, by lipase $\left(50 \mathrm{U} \mathrm{mg}^{-1}\right.$ and $\alpha$-amylase $\left(15 \mathrm{U} \mathrm{mg}^{-1}\right)$, respectively, at a final concentration of $1 \mathrm{mg} \mathrm{m}^{-1}$ in phosphate buffer $(\mathrm{pH} 7 \cdot 0)$. The supernatants were incubated with these enzymes at $37^{\circ} \mathrm{C}$ for $2 \mathrm{~h}$ after which remaining activity was determined by a well diffusion assay.

Sensitivity to high temperature was determined by heat treatment of the supernatants at $100^{\circ} \mathrm{C}$ for $20 \mathrm{~min}, 100^{\circ} \mathrm{C}$ for $60 \mathrm{~min}$ and by sterilization $\left(121^{\circ} \mathrm{C}\right.$ for $\left.15 \mathrm{~min}\right)$.

\section{Stability of the antimicrobial activity at different $\mathrm{pH}$, refrigerated storage and organic solvents}

Bacteriocin-containing cell-free supernatants were adjusted to varying $\mathrm{pH}$ values, ranging between 3.0 and $11 \cdot 0$, with $5 \mathrm{~mol} \mathrm{l}^{-1} \mathrm{HCl}$ or $1 \mathrm{~mol} \mathrm{l}^{-1} \mathrm{NaOH}$, incubated at $28^{\circ} \mathrm{C}$ for $1 \mathrm{~h}$ and assayed for residual activity. To evaluate the stability over time, antimicrobial activity-containing supernatant was stored at -20 and $4^{\circ} \mathrm{C}$ for 60 days and activity was evaluated every 10 days. The effect of organic solvents was evaluated after concentration and treatment of active supernatants with 5,10 , and $15 \%$ ethanol.

\section{Mode of action}

To study the effect of antimicrobial compounds on sensitive cells, $2 \mathrm{ml}$ of a 10-fold concentrated (under vacuum), adjusted to $\mathrm{pH} 6.5$ and catalase treated, supernatant was added to $18 \mathrm{ml}$ of mMRS in which, after filtration through a $0 \cdot 22-\mu \mathrm{m}$ pore size filter (Nucleopore, Costar Corporation), the indicator strain $L b$. sakei LMG 2313 was inoculated at a cellular concentration of approx. $10^{3} \mathrm{CFU} \mathrm{ml}^{-1}$. As a negative control, the supernatant of $L b$. sanfranciscensis $7 \mathrm{H}$ (a strain which does not produce any antimicrobial compound), similarly treated as described above, was used. Cells were cultivated at $30^{\circ} \mathrm{C}$ for $24 \mathrm{~h}$ and at 2-h intervals, the optical density at $620 \mathrm{~nm}\left(\right.$ O.D. $\left.{ }_{620}\right)$ and the number of viable $L$ b. sakei LMG 2313 cells on mMRS agar plates was determined.

\section{Adsorption studies}

The effect of the $\mathrm{pH}$ on adsorption of bacteriocin onto producer cells was evaluated as reported by Yang et al. (1992) and Todorov et al. (1999). After $18 \mathrm{~h}$ of growth, the culture broth was adjusted to $\mathrm{pH} 6.0$ and incubated at $4^{\circ} \mathrm{C}$ for $30 \mathrm{~min}$. After centrifugation, cell-free supernatant was assayed for bacteriocin activity not adsorbed onto the cells while the cells were washed with sodium phosphate buffer, $\mathrm{pH} 6 \cdot 5$, centrifuged, resuspended in $0 \cdot 1 \mathrm{~mol}^{-1} \mathrm{NaCl}(\mathrm{pH}$ $2 \cdot 0$ ) (adjusted with $5 \%$ phosphoric acid) and mixed with a magnetic stirrer for $1 \mathrm{~h}$ at $4^{\circ} \mathrm{C}$. Cell suspension was centrifuged (4500 $g$ for $30 \mathrm{~min}$ ) and the resulting supernatant was neutralized and tested for antibacterial activity released by the cells after treatment at $\mathrm{pH} 2 \cdot 0$.

\section{Production study}

In order to determine optimal conditions for bacteriocin production, tests were performed to evaluate the effect of culture medium, temperature, time of incubation and $\mathrm{pH}$. Cells of the producer strain were cultivated at 15, 30, 37 and $42^{\circ} \mathrm{C}$ for $48 \mathrm{~h}$ in mMRS, MRS, SDB and a synthetic modified Amino Acid Assay Medium (AAAM) (Difco) modified as follows: ammonium chloride and sodium chloride were omitted. Other modifications concerned the reduction of dextrose $\left(5 \mathrm{~g} \mathrm{l}^{-1}\right.$ instead of $\left.50 \mathrm{~g} \mathrm{l}^{-1}\right)$, sodium acetate $\left(2.5 \mathrm{~g} \mathrm{l}^{-1}\right.$ instead of $\left.40 \mathrm{~g}^{-1}\right)$ and the addition of diammonium citrate $\left(1 \mathrm{~g} \mathrm{l}^{-1}\right)$, Tween-80 $\left(0 \cdot 5 \mathrm{~g} \mathrm{l}^{-1}\right)$ and maltose $\left(5 \mathrm{~g} \mathrm{l}^{-1}\right)$. The final $\mathrm{pH}$ of the medium was $6 \cdot 0$. 
After selection of the optimal medium and growth conditions, the influence of a constant $\mathrm{pH}$ during the growth was evaluated by maintaining a stable $\mathrm{pH}$ of $6 \cdot 0$ by the periodic addition of $6 \mathrm{~mol} \mathrm{l}^{-1} \mathrm{NaOH}$. Antimicrobial activity contained in the cell-free supernatant was evaluated each $3 \mathrm{~h}$ by a well diffusion assay as described above.

\section{Sourdough production and evaluation of in situ antimicrobial activity}

Lactobacilli and lactococci used as sourdough starters were cultured in SDB (Kline and Sugihara 1971) or mMRS, and M17 (Difco) broth, respectively, at $30^{\circ} \mathrm{C}$ for $24 \mathrm{~h}$. Cells were harvested by centrifugation at $6500 \mathrm{~g}$ for $10 \mathrm{~min}$, washed twice with sterile, distilled water, and then resuspended in sterile distilled water; the cell suspension, diluted $1: 10$, gave an O.D. 620 of $0 \cdot 25$. Wheat flour, containing $12.5 \%$ moisture; protein $(\mathrm{N} \times 5.70) 11 \%$ of dry matter (DM); fat $1.82 \%$ of DM; and ash, $0.60 \%$ of DM. Wheat flour $(50 \mathrm{~g})$, tap water $(22.4 \mathrm{ml})$, and cellular suspension $(7.6 \mathrm{ml})$ of one or more micro-organisms, was used to produce doughs with a dough yield (weight of the dough/ weight of the flour $\times 100$ ) of 160 and with a cellular concentration of about $10^{4} \mathrm{CFU} \mathrm{g}^{-1}$. Doughs $(80 \mathrm{~g})$ were individually placed in glass beaker and incubated at $30^{\circ} \mathrm{C}$ for $21 \mathrm{~h}$. A reference dough (R) without starter was produced and incubated as above described. In case the bacteriocincontaining supernatant was added to the dough instead of the producer strain, an equivalent volume of water $(30 \mathrm{ml})$ was removed in order to obtain dough with the same dough yield.

\section{Extraction of antimicrobial activity from sourdough}

At the end of fermentation $\left(30^{\circ} \mathrm{C}\right.$ for $\left.21 \mathrm{~h}\right), 10 \mathrm{~g}$ of each dough was suspended in $90 \mathrm{ml}$ of a $40 \%$ acetonitrile $-0 \cdot 1 \%$ (v/v) trifluoroacetic acid solution (on account of the hydrophobic nature of the inhibitory substances), homogenized, centrifuged at $15000 \mathrm{~g}$ for $10 \mathrm{~min}$, freeze-dried and then resuspended in $4 \mathrm{ml}$ of a $50 \%(\mathrm{v} / \mathrm{v})$ ethanol solution. The suspension extracted from a dough of flour and water, without the addition of starter LAB and incubated as above reported, was assayed in order to avoid false positive results due to the putative inhibitory activity produced by micro-organisms spontaneously growing in the dough. All suspensions were subjected to a well diffusion assay.

\section{Sourdough characteristics}

Sourdoughs were analysed immediately after mixing and after 6 and $21 \mathrm{~h}$ of fermentation. Depending on the LAB added as starters, plate counts were performed using MRS, $\mathrm{SDB}$, MRS containing sucrose instead of glucose (final $\mathrm{pH}$ $5 \cdot 0$ ) (MRSs) or $\mathrm{M} 17$ media, at $30^{\circ} \mathrm{C}$ for $72 \mathrm{~h}$. The presence of micro-organisms added as starter was also confirmed by microscopic analysis and, after culture isolation and purification, by phenotypic identification with API 50 CHL System (bioMérieux). The $\mathrm{pH}$ was determined by a Corning pH-Meter (Corning, Halstead, Essex, UK) on the diluted (10 $\mathrm{g}$ of dough and $90 \mathrm{ml}$ of distilled water) and homogenized (Classic Blender; PBI International, Milan, Italy) sourdoughs.

\section{Statistical analyses}

All the experiments, with the exception of dough fermentations (performed in duplicate) were carried out in three independent experiments and the results are shown as mean \pm S.D.

\section{RESULTS}

\section{Screening of sourdough Lactobacillus spp. for antimicrobial compound production}

A total of 437 Lactobacillus strains, isolated from 70 sourdoughs, were initially screened for antimicrobial compound production against four indicator strains $(L b$. farciminis $\mathrm{CC10}$, Lb. sakei LMG 2313, Lb. delbrueckii ssp. bulgaricus B397, and Listeria innocua 4202) by means of the agar-spot deferred method. In this step the possible inhibitory effect of the organic acids and of hydrogen peroxide was not excluded. Eighty-five of the 437 strains tested produced an inhibition zone against one or more indicators. Subsequently, the cellfree supernatants from the 85 strains were treated with catalase, neutralized, sterilized by filtration and tested by the well diffusion assay against the same four indicators. Only five unidentified lactobacilli (Lactobacillus spp. 3DM, 4DE, 8CF, 2MF8 and CS1) were found to maintain the antimicrobial activity against some indicators, showing a measurable clear zone around the well. To better evaluate the inhibitory activity of the five producer strains, their cell-free supernatants were tested against other 53 indicators (Table 1). All antimicrobial activities tested were active against $L b$. sakei LMG 2313 while the inhibition of other lactobacilli was dependent on the producer strain. Lactobacillus spp. 2MF8 and CS1 showed the largest spectra (13 and 11 strains of 57 were inhibited, respectively). Leuconostoc spp. were inhibited only by Lactobacillus spp. 4DE and CS1, while many of the other microorganisms used as indicators (Listeria, Streptococcus, Weissella, Bacillus, and Saccharomyces spp.) were not inhibited by any producer strains.

The above five lactobacilli, not identified previously, were subjected to phenotypic identification and $16 \mathrm{~S}$ rDNA 
sequencing, and were thus classified as $L b$. pentosus $2 \mathrm{MF} 8$, Lb. pentosus $8 \mathrm{CF}, L$ b. plantarum $3 \mathrm{DM}$, and $L$ b. plantarum 4DE. Strain CS1 remained unclassified as it probably belongs to a new Lactobacillus spp. Work is in progress to further classify this strain.

\section{Effect of enzymes and heat treatments}

The cell-free supernatants from the five strains producing antimicrobial substances were assayed for sensitivity to hydrolytic enzymes and heat. All antibacterial compounds produced by those strains were inactivated by proteolytic enzymes (Table 2), indicating that the inhibitory compounds are of proteinaceus nature, a general characteristic of bacteriocins. As protein compounds inhibitory to closely related bacteria can be included in the category of the bacteriocins (Tagg et al. 1976; Jack et al. 1995) and because the substances of this study have not yet been characterized for amino acid and nucleotide sequences, they will be referred to as BLIS. The cell-free supernatants derived from strains Lb. plantarum 4DE and 3DM, and Lactobacillus spp . CS1, were insensitive to $\alpha$-amylase, whereas those derived from $L b$. pentosus $8 \mathrm{CF}$ and $2 \mathrm{MF} 8$ were sensitive. Similarly, the supernatant activity from $L b$. plantarum $4 \mathrm{DE}$ and Lactobacillus spp. CS1 was not inhibited by lipase, whereas that from $L b$. pentosus $8 \mathrm{CF}$ and $2 \mathrm{MF} 8$, and $L$ b plantarum 3DM was inhibited. Moreover, the supernatants from strains CS1, $8 \mathrm{CF}$ and $2 \mathrm{MF} 8$ were resistant to treatment of

Table 2 Effect of enzymes, heat treatment, pH, storage, and organic solvent on inhibitory activity of sourdough lactobacilli determined by well diffusion assay*

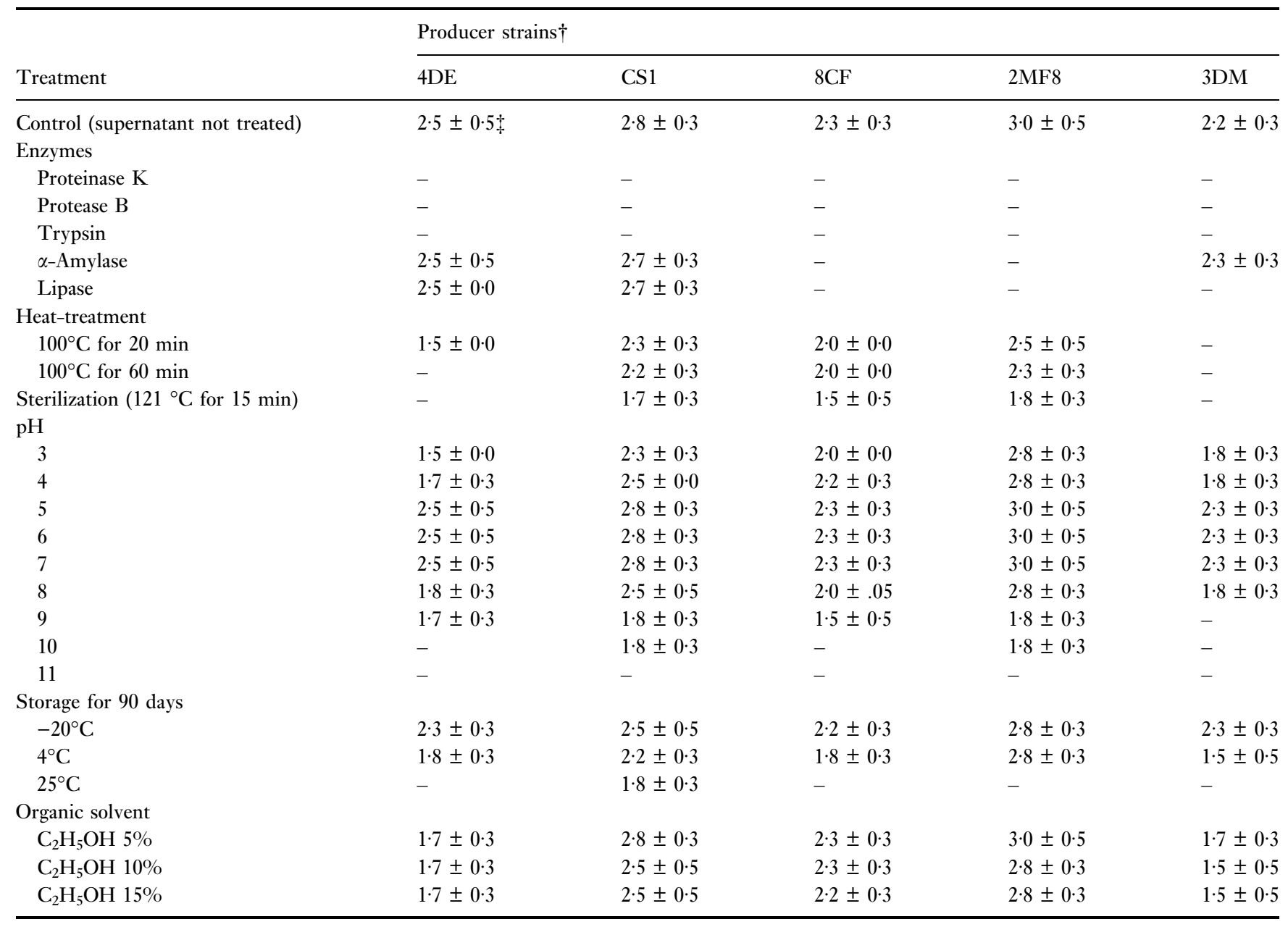

*All assays were conducted with $L b$. sakei LMG 2313 as indicator strain.

$\dagger$ Producer strains are termed by the collection reference abbreviation: 4DE, Lb. plantarum; CS1, Lactobacillusspp.; 8CF and 2MF8, Lb. pentosus; 3DM, Lb. plantarum.

tWidth of the inhibition zone $(\mathrm{mm})$.

'-, No inhibition zone. Results indicate mean \pm S.D. of three independent experiments.

(C) 2004 The Society for Applied Microbiology, Journal of Applied Microbiology, 96, 521-534, doi:10.1111/j.1365-2672.2004.02171.x 
$100^{\circ} \mathrm{C}$ for $60 \mathrm{~min}$, and were partially inactivated by sterilization, while the activity contained in the cell-free supernatants from $L b$. plantarum 4DE and 3DM were partially or totally lost, respectively, after heat treatment at $100^{\circ} \mathrm{C}$ for $20 \mathrm{~min}$ (Table 2).

\section{Stability of the antimicrobial activity at different $\mathrm{pH}$ values, refrigerated storage and after treatments with an organic solvent}

Stability of antimicrobial activity was evaluated under various conditions. All samples retained full activity in the pH range 5-7 (Table 2). Cell-free supernatant from Lactobacillus spp. CS1, Lb. pentosus $2 \mathrm{MF} 8$ and $L$ b. pentosus $8 \mathrm{CF}$ remained fully active at $\mathrm{pH}$ values ranging from 3 to 8 while a reduction of activity was observed above such value. The strains $L b$. plantarum $4 \mathrm{DE}$ and 3DM showed a reduction of activity also at $\mathrm{pH}$ values of 3-4 and 8-9 (Table 2).

The activity of Lactobacillus spp. CS1 was stable during frozen $\left(-20^{\circ} \mathrm{C}\right)$ and refrigerated $\left(+4^{\circ} \mathrm{C}\right)$ storage for at least 3 months and partially lost when stored at $25^{\circ} \mathrm{C}$. The inhibitory activities produced by the other strains were completely lost after 3 months at $25^{\circ} \mathrm{C}$ and retained the maximum activity only when stored at $-20^{\circ} \mathrm{C}$ (Table 2). The antimicrobial activity of supernatants from Lactobacillus spp. CS1, Lb. pentosus 8CF and Lb. pentosus $2 \mathrm{MF} 8$ was completely retained in the presence of $15 \%$ or less ethanol, while the $L b$. plantarum 4DE and 3DM activities were reduced by ethanol at concentrations of $5 \%$ and higher.

\section{Mode of action of the antibacterial substances}

The addition of cell-free supernatant of $L b$. pentosus $2 \mathrm{MF} 8$ to $1 \times 10^{3} \mathrm{CFU} \mathrm{m}{ }^{-1}$ cells of the indicator strain Lb. sakei LMG 2313 arrested cell growth for the first $10 \mathrm{~h}$ after which growth resumed, ultimately reaching a cell density of $2.6 \times 10^{6} \mathrm{CFU} \mathrm{ml}^{-1}$ after $24 \mathrm{~h}$. In contrast, in the presence of a cell-free supernatant from a negative control strain (nonproducer), the indicator strain showed a normal growth reaching $1 \times 10^{6} \mathrm{CFU} \mathrm{ml}^{-1}$ after $10 \mathrm{~h}$ and $1.8 \times$ $10^{9} \mathrm{CFU} \mathrm{ml}^{-1}$ at $24 \mathrm{~h}$. The other four producer strains displayed a similar inhibition of the indicator.

\section{Adsorption studies}

Yang et al. (1992) reported that 93-100\% of the bacteriocin is adsorbed to produce cells at $\mathrm{pH} 6.0$ while $<5 \%$ adsorption took place at $\mathrm{pH} 1 \cdot 5-2 \cdot 0$.

Under the conditions tested the activity of cell-free supernatant of the five producer strains obtained after treatment of cells at $\mathrm{pH} 2 \cdot 0$ was very low indicating that the inhibitory compound is completely released in the medium during growth and no significant absorption takes place following adjustment of the $\mathrm{pH}$ of the broth to 6.0 before harvesting the cells by centrifugation.

\section{Production studies}

The maximum activity of the BLIS produced by the five sourdough strains, as evaluated by the critical dilution assay against $L$ b. sakei LMG 2313, was obtained in MRS after 12$22 \mathrm{~h}$ of incubation at $30^{\circ} \mathrm{C}$ (values of 40 and $160 \mathrm{AU} \mathrm{ml}$ for $\mathrm{Lb}$. plantarum 4DE and 3DM, respectively, and of $320 \mathrm{AU} \mathrm{ml} \mathrm{m}^{-1}$ for Lb. pentosus and Lactobacillus spp. CS1). BLIS production, growth and $\mathrm{pH}$ kinetics for Lb. pentosus $2 \mathrm{MF} 8$ are shown in Fig. 1.

After $22 \mathrm{~h}$ of growth at $30^{\circ} \mathrm{C}$ or after $18 \mathrm{~h}$ at $37^{\circ} \mathrm{C}$ the activity decreased and higher reductions were observed at higher/lower temperature (data not shown). Maintaining a constant $\mathrm{pH}$ of 6.0 during growth did not improve the inhibitory activity. Similar results were obtained, only for Lactobacillus spp. CS1, using the synthetic mAAAM (Difco), not containing complex nitrogen sources, instead of MRS while no inhibitory activity was detected in mAAAM medium after growth of the other producer strains.

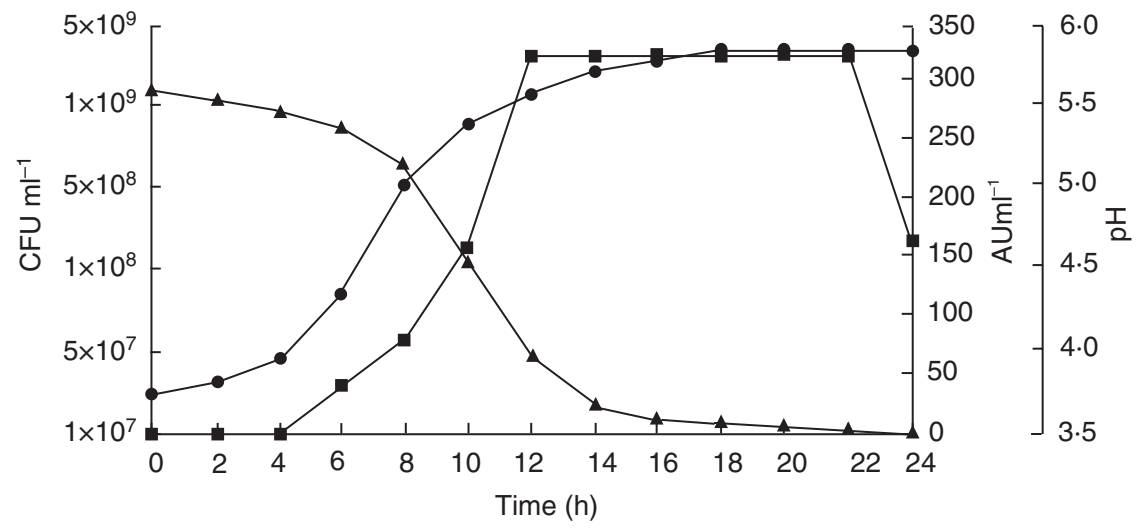

Fig. 1 Lactobacillus pentosus 2MF8 growth and BLIS production at uncontrolled $\mathrm{pH}$. Colony-forming units $\left(\mathrm{CFU} \mathrm{ml^{-1 }}\right)$, $\mathbf{0}$ BLIS titre $\left(\mathrm{AU} \mathrm{ml} l^{-1}\right), \mathbf{a} ; \mathrm{pH}, \mathbf{\Delta}$ 


\section{Evaluation of Lc. lactis activity against sourdough LAB}

In order to compare the antibacterial spectrum of sourdough $\mathrm{LAB}$ with that of bacteriocin-producer strains isolated from other foods, Lc. lactis M30 and M36, isolated from raw, unmalted barley (Hartnett et al. 2002), were evaluated against $L b$. sakei LMG 2313, Lb. sanfranciscensis (six strains), Lb. plantarum (six strains), B. subtilis 813 , and B. cereus 660 (Table 3). Lactococcus lactis M30 and M36 were characterized by an almost identical spectrum of activity. They inhibited 12 and 13 indicator strains of 15 tested, respectively, and showed no activity vs Lb.sanfranciscensis CB1 and 7H (Table 3). Antimicrobial compounds from lactococci showed an inhibition of $800 \mathrm{AU} \mathrm{ml}^{-1}$ against $L b$. sakei LMG2313 and were also characterized by an high antilisterial activity (25 $\left.600 \mathrm{AU} \mathrm{m}^{-1}\right)$ (Hartnett et al. 2002).

\section{Evaluation of the in situ antibacterial activity}

In order to evaluate the capability of the BLIS-producing $\mathrm{LAB}$ to inhibit the indicator strains in situ, Lc. lactis M30 and Lb. pentosus 2MF8 (BLIS producers); Lc. lactis Q13 and Lb. plantarum 20 (negative controls); Lb. sakei LMG 2313, $L b$. plantarum 20 and $L b$. sanfranciscensis $\mathrm{CB} 1$ (indicator strains) were preliminarily used as individual starter to produce sourdoughs. Starting at a $\mathrm{pH}$ of $5.98-6.04$, the six

Table 3 Inhibitory activity of selected bacteriocin-producing Lactococcus lactis determined by well diffusion assay

\begin{tabular}{lll}
\hline & \multicolumn{2}{l}{ Producer strains* } \\
\cline { 2 - 3 } Indicator strains & $\mathrm{M} 30$ & $\mathrm{M} 36$ \\
\hline Lb. sakei LMG 2313 & $6 \cdot 5 \pm 0 \cdot 5 \dagger$ & $6 \cdot 5 \pm 0 \cdot 5$ \\
Lb. sanfranciscensis CB1 & - & - \\
Lb. sanfranciscensis A22 & $3 \cdot 0 \pm 0 \cdot 5$ & $2 \cdot 8 \pm 0 \cdot 3$ \\
Lb. sanfranciscensis $9 \mathrm{~N}$ & $2 \cdot 8 \pm 0 \cdot 3$ & $2 \cdot 7 \pm 0 \cdot 3$ \\
Lb. sanfranciscensis 7H & - & - \\
Lb. sanfranciscensis 13R & $3 \cdot 0 \pm 0 \cdot 5$ & $2 \cdot 8 \pm 0 \cdot 3$ \\
Lb. sanfranciscensis I1 & $2 \cdot 8 \pm 0 \cdot 3$ & $2 \cdot 8 \pm 0 \cdot 3$ \\
Lb. plantarum 3DM & $1 \cdot 8 \pm 0 \cdot 3$ & $2 \cdot 0 \pm 0 \cdot 0$ \\
Lb. plantarum 20 & $6 \cdot 0 \pm 0 \cdot 5$ & $6 \cdot 0 \pm 0 \cdot 5$ \\
Lb. plantarum AD4 & $1 \cdot 8 \pm 0 \cdot 3$ & $1 \cdot 8 \pm 0 \cdot 3$ \\
Lb. plantarum CF1 & $3 \cdot 3 \pm 0 \cdot 3$ & $3 \cdot 0 \pm 0 \cdot 5$ \\
Lb. plantarum 13 & $1 \cdot 8 \pm 0 \cdot 3$ & $1 \cdot 5 \pm 0 \cdot 5$ \\
Lb. plantarum 4DE & $1 \cdot 8 \pm 0 \cdot 3$ & $1 \cdot 5 \pm 0 \cdot 5$ \\
B. subtilis 813 & $6 \cdot 2 \pm 0 \cdot 3$ & $5 \cdot 8 \pm 0 \cdot 3$ \\
B. cereus 660 & - & $4 \cdot 2 \pm 0 \cdot 3$ \\
\hline
\end{tabular}

*Producer strains are termed by the collection reference abbreviation: M30-M36, Lc. lactis. The strain M30 is a BLIS producer.

$\dagger$ Width of the inhibition zone (mm).

'-', No inhibition zone. Results indicate mean \pm S.D. of three independent experiments. sourdoughs fermented with individual strains reached a $\mathrm{pH}$ of 4.07-4.82 after $21 \mathrm{~h}$ of fermentation (doughs A-F, Table 4). Lactobacillus sakei LMG 2313, Lc. lactis M30 and Lc. lactis Q13 were the LAB exhibiting the lowest acidifying ability. All six strains grew in the dough from 2.6$5.9 \times 10^{4}$ to $2.9 \times 10^{8}-2.6 \times 10^{9} \mathrm{CFU} \mathrm{g}^{-1}$ after $21 \mathrm{~h}$ of fermentation (Table 4). During the same time period, mesophilic LAB reached a cell density of $3.7 \times 10^{6} \mathrm{CFU} \mathrm{g}^{-1}$ in the reference dough produced without starter (dough R, Table 4).

The results of the sourdough fermentation obtained by mixed starters are also reported in Table 4. A selective growth of $L b$. sakei LMG 2313, Lb. plantarum 20, and $L b$. pentosus 2MF8 was possible using the MRSs. This medium was useful to easily distinguish the above strains from $L c$. lactis or from $L b$. sanfranciscensis after associate growth. In the sourdoughs started with the associations Lb. pentosus 2MF8-Lb. sakei LMG 2313 (dough no. 1) or Lc. lactis M30-Lb. sakei LMG 2313 (dough no. 2) the BLIS producers showed a final cell concentration similar to that obtained at the end of individual fermentation $\left(4.4 \times 10^{9} \mathrm{vs}\right.$. $2.6 \times 10^{9} \mathrm{CFU} \mathrm{g}^{-1}$ and $1.4 \times 10^{9}$ vs. $1.5 \times 10^{9} \mathrm{CFU} \mathrm{g}^{-1}$, respectively). In contrast, in the presence of $L b$. pentosus 2MF8 (dough no. 1) the indicator strain Lb. sakei LMG 2313 showed a decrease with respect to the individual fermentation $\left(6 \times 10^{7}\right.$ vs. $\left.2.9 \times 10^{8} \mathrm{CFU} \mathrm{g}^{-1}\right)$.

In the presence of Lc. lactis M30 (dough no. 2) the indicator strain $L b$. sakei LMG 2313 appears to reduce its growth, i.e. after $21 \mathrm{~h}$ of fermentation the cellular concentration of this organism does not exceed $4 \cdot 0 \times 10^{6} \mathrm{CFU} \mathrm{g}^{-1}$. The in situ inhibitory activity of Lc. lactis M30 was also obvious against $L b$. plantarum 20 , which discontinued growth at a cell density of $4 \cdot 1 \times 10^{6} \mathrm{CFU} \mathrm{g}^{-1}$ at the end of fermentation (dough no. 3 ). In both cases the indicator strains were not easily distinguishable from contaminating sourdough LAB, which reached similar concentration (dough R). Both indicator strains exhibited normal growth, similar to that obtained during individual fermentations, when associated with the negative control strains $L b$. plantarum 20 or Lc. lactis Q13 (dough nos. 4 and 5).

In order to exclude the possibility that the observed inhibition was dependent on substrate competition, the active, neutralized and catalase-treated cell-free supernatant from the $L b$. pentosus $2 \mathrm{MF} 8$ or $L c$. lactis M30, instead of viable cells of the same strains, was added to the doughs fermented with $L$ b. sakei LMG 2313 or Lb. plantarum 20, respectively (dough nos. 9 and 10). Also in these cases the indicator strains grew only to a cell density not exceeding $3 \cdot 2 \times 10^{6}$ and $5 \times 10^{6} \mathrm{CFU} \mathrm{g}^{-1}$, respectively, while the final $\mathrm{pH}$ of the dough showed values similar to the reference dough produced without starters (dough $\mathrm{R}$ ).

With the aim to evaluate the possible contribution of the antibacterial compound producer strains on the implantation 
Table 4 Kinetics of growth and acidification of selected lactobacilli and lactococci during individual (A-F) and mixed (1-10) sourdough fermentation

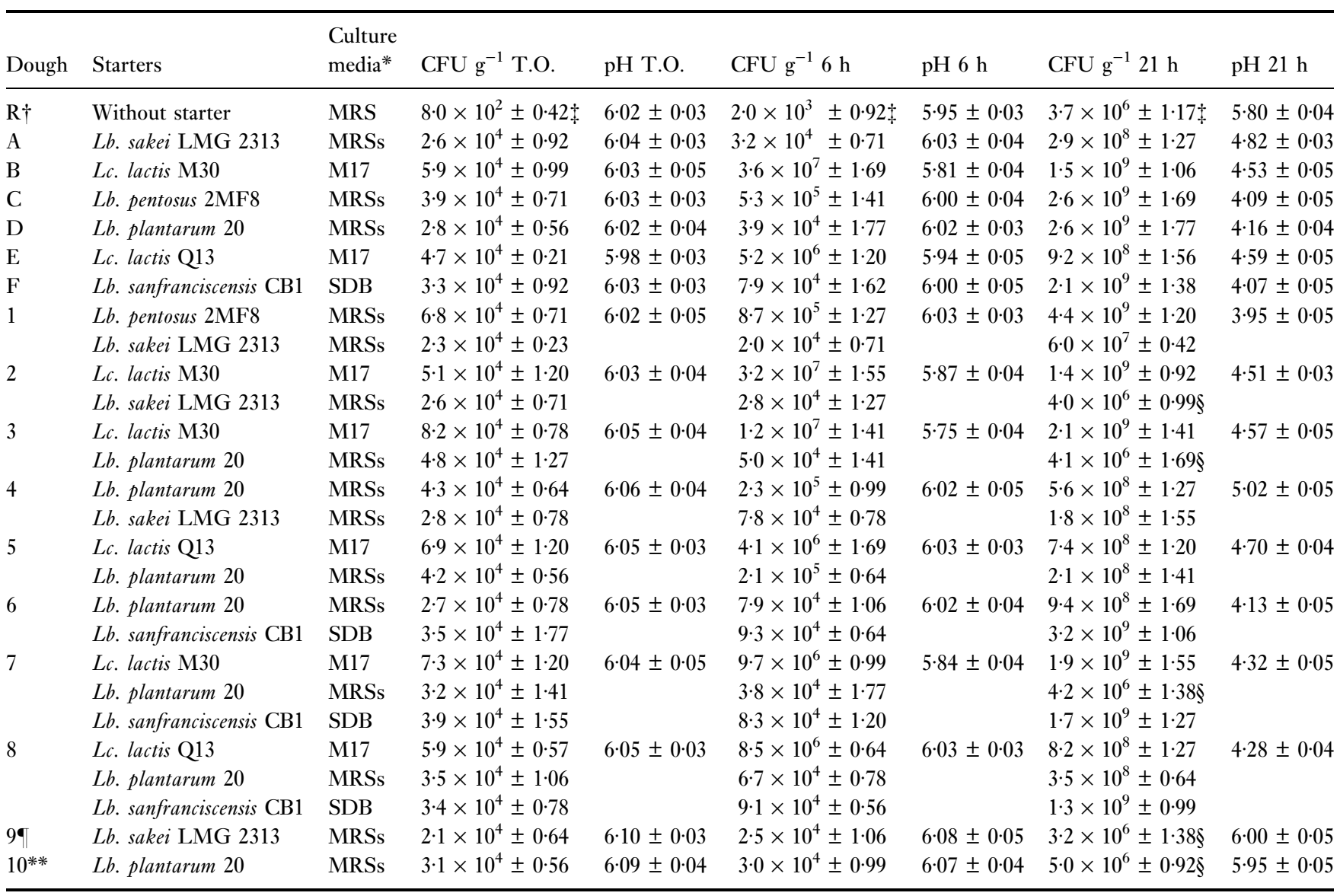

* See Materials and methods.

$\dagger$ Reference dough: produced without adding starter $\mathrm{LAB}$, incubated at $30^{\circ} \mathrm{C}$.

$\$$ Total meshophilic LAB.

\$Not distinguishable from contaminating LAB

-Dough added of BLIS-containing cell-free, neutralized and catalase-treated supernatant from Lb. pentosus 2MF8.

***Dough added of BLIS-containing cell-free, neutralized and catalase-treated supernatant from Lc. lactis M30.

Results indicate mean \pm S.D. of two independent experiments.

and/or stability of a nonsensitive strain growing in complex populations, and thus speculate on the importance of bacteriocins on regulating the interactions among microorganisms, sourdoughs produced with a combination of three LAB (BLIS or bacteriocin producer, nonsensitive and sensitive strain) were produced. Because of the higher inhibitory activity produced by this strain, only $L c$. lactis M30 was used in this experiment. When used as a cell mixture, Lb. plantarum 20 and $L b$. sanfranciscensis CB1 grew, after $21 \mathrm{~h}$ of fermentation, to a final cell density of $9 \cdot 4 \times 10^{8}$ and $3 \cdot 2 \times 10^{9} \mathrm{CFU} \mathrm{g}^{-1}$, respectively (dough no. 6) similar to those reached at the end of individual fermentations (doughs D and F, respectively). Nevertheless we observed (data not shown) that after repeated inoculation of a sourdough started with the typical association $L b$. sanfranci-
scensis-Lb. plantarum, or after the continuous use of a sourdough started with $L b$. sanfranciscensis alone, LAB showing fast growth kinetics can prevail over $L b$. sanfranciscensis, greatly reducing the starter performance. When $L c$. lactis M30 was used as a starter besides $L b$. plantarum 20 and $L b$. sanfranciscensis CB1 (dough no. 7, Table 4), only $L b$. plantarum 20 was inhibited, confirming the results obtained when Lc. lactis M30 grew in presence of only $L b$. plantarum 20 (dough no. 3). In presence of Lc. lactis Q13 (not a bacteriocin producer) instead of Lc. lactis M30, no inhibition against $L$ b. plantarum 20 was observed (dough no. 8). In general, the sourdough fermented by the association between Lc. lactis Q13 and sourdough lactobacilli (dough nos. 5 and 8) or Lc. lactis M30 and nonsensitive lactobacilli (dough no. 7), showed, after $21 \mathrm{~h}$ of fermentation, higher 
$\mathrm{pH}$ values with respect to the individual fermentations obtained by $L b$. plantarum 20 or $L b$. sanfranciscensis CB1 (Table 4), probably indicating a competition for carbohydrates between micro-organisms (Gobbetti et al. 1994). However, when $L c$. lactis M30 was associated with a sensitive strain (dough nos. 2 and 3), similar $\mathrm{pH}$ were obtained with respect to the Lc. lactis M30 mono-culture.

The efficacy of the antimicrobial compounds produced in situ by Lc. lactis M30 and Lb. pentosus $2 \mathrm{MF} 8$ was also confirmed by extracting the inhibitory activities from doughs. Such bacteriocin preparations inhibited the indicator strains $L b$. plantarum 20 and $L b$. sakei LMG 2313 showing an activity of 80 and $32 \mathrm{AU} \mathrm{ml}{ }^{-1}$, respectively. The massive loss of activity after extraction was probably because of the binding of bacteriocins to dough components (Gänzle and Vogel 2003). No inhibitory activity was extracted from the reference dough $(\mathrm{R})$ fermented for $21 \mathrm{~h}$ without addition of starter, indicating that the contaminating microflora growing spontaneously in the dough did not produce any antimicrobial compound.

\section{DISCUSSION}

Of $437 \mathrm{LAB}$ isolated from 70 sourdoughs, five strains (two $L b$. plantarum, two $L b$. pentosus, and one unclassified Lactobacillus spp.), representing the $1 \cdot 1 \%$ of the strain tested, produced antibacterial compounds, which were inactivated by proteolytic enzymes, indicating them to be bacteriocins. According to Tagg et al. (1976) and Jack et al. (1995) the five antimicrobial compounds found in this study can be regarded as BLIS as they possess bacteriocin requisites but have not yet been characterized for amino acid and encoding nucleotide sequences. In particular, due to the sensitivity to $\alpha$-amylase and lipase treatments, BLIS from the two strains of $L b$. pentosus could preliminarily be regarded as compounds belonging to the fourth class of bacteriocins, as proposed by Klaenhammer (1993). Nevertheless, as affirmed by Nes et al. (1996), bacteriocins of the fourth class have not yet been characterized adequately at the biochemical level and the experimental data suggest that such complex activities may be artefacts caused by interactions between constituents from the cells or the growth medium and the undefined bacteriocin activities are likely to be regular peptide bacteriocins. Indeed, proper purification of such activities leads to the isolation of regular peptide bacteriocins (Jiménez-Diaz et al. 1995). For the first time, BLIS production by $L b$. pentosus isolated from sourdough is reported. Phenotypically, this species is closely related to $L b$. plantarum, a lactic acid bacterium with potential application as a starter for the fermentation of vegetable, meat, milk, and fish products (Suma et al. 1998; Corsetti and Gobbetti 2002). As stated by Messens and De Vuyst (2002), and confirmed by our results, the frequency of isolating bacteriocin-producing sourdough LAB is rather low. The same finding can be extended to LAB isolated from other foods. Ennahar et al. (1996) showed antagonistic effects caused by antimicrobial substances other than organic acids just from six isolates of 1962 bacteria from Munster cheese. In contrast, $24 \%$ of the LAB isolates from raw milk showed inhibitory activity after neutralization and treatment with catalase (Rodríguez et al. 2000). From an ecological point of view, a high frequency of bacteriocin-producers may be a reflection of strong competition among micro-organisms in the ecosystem they live (Navarro et al. 2000). Nevertheless, during sourdough fermentation, other factors such as metabolic adaptation to the main carbohydrates available in the dough, in particular utilization of maltose resulting in a high energy yield, growth requirements which match the environmental conditions of the sourdough fermentation (Gobbetti and Corsetti 1997; Gänzle and Vogel 2003) are involved in strain adaptation besides bacteriocin production. Based on their host range inhibition, their sensitivity to enzymes and heat treatment, and the stability under different conditions, the five BLIS are considered to be different from each other. Nevertheless, all BLIS compounds were characterized by a limited inhibitory spectrum and showed no inhibition against Bacillus ssp., which are known to cause rope formation in bread (Röcken and Spicher 1993; Rosenquist and Hansen 1998), Listeria innocua and yeasts (De Vuyst and Vandamme 1994b). This is not surprising, because bacteriocins of LAB are usually inhibitory to closely related bacteria or to those competing for the same ecological niche (Klaenhammer 1988).

If the antimicrobial substances produced by sourdough $\mathrm{LAB}$ are resistant to baking and are active at the physical conditions of bread, they may control growth of spoilage organisms by microbial interaction (Rosenkvist and Hansen 1995). As demonstrated by the in vitro characterization, some BLIS compounds (e.g. those from Lactobacillus spp. CS1 and $L b$. pentosus 8CF and 2MF8) show potentially interesting properties for bread-making, such as resistance to heat, stability at refrigerated storage and low $\mathrm{pH}$, and activity in the presence of a high ethanol concentration. In bakery practice the sourdough is stored at $+4^{\circ} \mathrm{C}$ for variable periods of time between repeated inoculation, while during bread baking the temperature of the crumb reaches $98^{\circ} \mathrm{C}$ for a period of up to $1 \mathrm{~h}$ (Gänzle and Vogel 2003). Moreover, in the case of sourdough bread, the $\mathrm{pH}$ can reach values below 4.0 at the end of fermentation and a final concentration of $10 \mathrm{~g} \mathrm{~kg}^{-1}$ ethanol can be reached in the dough, due to yeast fermentation (Corsetti et al. 1994; Gobbetti et al. 1995). Resistance to heat and acidity have been reported also for bavaricin A (Larsen et al. 1993) and plantaricin ST31 (Todorov et al. 1999) produced by the sourdough-isolated Lb. sakei MI401 and Lb. plantarum ST31, respectively. 
The maximum activity for the five BLIS, as evaluated by the critical dilution method against Lb. sakei LMG2313, was obtained after $22 \mathrm{~h}$ of fermetation at $30^{\circ} \mathrm{C}$ in mMRS medium and varied between 40 and $320 \mathrm{AU} \mathrm{ml}^{-1}$. The above combination time/temperature characterizes the type II sourdoughs employing a one-stage fermentation process (Messens and De Vuyst 2002; Messens et al. 2002). Thus, the five BLIS-producing LAB can be considered good candidates as starter cultures for such type of sourdough fermentation. All five BLIS showed a bacteriostatic mode of action, a characteristic which has been reported also for Plantaricin C19 (Atrih et al. 2001), lactocin 27 (Upreti and Hinsdill 1975) and leuconocin S (Lewus et al. 1992). Nevertheless, as observed by Leroy and De Vuyst (2000), the concentration and purity of the preparation, the type of broth used, the sensitivity of the indicator strain, and the density of the cell suspension applied are all factors that can influence the antibacterial mode of action of the bacteriocins. Most research on bacteriocins aimed to demonstrate the possibility to control spoilage and/or pathogenic growth in foods. The most important cause of bread spoilage is inflicted by growth of Bacillus species which cause ropiness. However, rope formation can occur in unacidified wheat bread (Messens and De Vuyst 2002), while sourdough fermentation can delay growth of rope-causing Bacillus spp. in bread (Gänzle 1998) or control growth of food-borne pathogens such as B. subtilis (Rosenkvist and Hansen 1995), mainly due to acetic acid production by heterofermentative LAB. Moreover, bacteriocin production by LAB may be considered as a desirable property when selecting more competitive starters for implantation and stability during repeated use (Todorov et al. 1999). As stated by Gänzle and Vogel (2003) 'a reproducible and controlled composition and activity of the sourdough microflora is paramount to achieve a constant quality of sourdough bread.' The same authors attributed the stable persistence of $L b$. reuteri in an industrial sourdough fermentation to reutericyclin production (Gänzle and Vogel 2003). Among sourdough LAB, Lb. sanfranciscensis can be considered a key bacterium as it possesses very interesting technological properties (Gobbetti and Corsetti 1997; Gänzle and Vogel 2003). However, during repeated inoculation for the continuous use of a sourdough, $L b$. sanfranciscensis as well as other strains eventually added as a starter, can be superseded by more competitive LAB derived from either the raw material or the bakery environment.

Based on the above considerations, with the aim to improve the implantation of technologically useful strains in the dough, we evaluated the possibility to use a bacteriocinproducer $\mathrm{LAB}$ in co-culture with $L b$. sanfranciscensis $\mathrm{CB} 1$, a strain with excellent technological performance (Gobbetti et al. 1994; Gobbetti and Corsetti 1997). Besides Lb. pentosus 2MF8, showing the widest inhibitory spectrum among the BLIS producers characterized in this study, two Lc. lactis isolated from raw unmalted sorghum and barley, and previously recognized as potent bacteriocin producers (Hartnett et al. 2002) were evaluated. Together with $L b$. panis, Lb. pontis, Lb. reuteri, Lb. johnsonii, Lb. fermentum, Lb. delbrueckii, Lb. acidophilus, Lb. brevis, Lb. amylovorus, and Lb. sanfranciscensis, $L c$. lactis represents the dominant strains in the type II sourdoughs (Messens and De Vuyst 2002). Higher inhibitory activity, wider spectrum of inhibition and lower acidification during sourdough fermentation characterized the Lc. lactis strains with respect to the LAB isolated from sourdough. While acid production is an important technological feature for a starter culture and antimicrobial activity being only of secondary concern, the contrary is true for a bacteriocinogenic strain to be used as a protective culture (Messens and De Vuyst 2002) or as a co-culture (Foulquié Moreno et al. 2003). Bacteriocinogenic cultures could be used in association with a selected starter, provided they are able to produce their antimicrobial activity in situ and the bacteriocinogenic compound is active in the food matrix. Up to date no studies have been carried out on the evaluation of in situ bacteriocin production by sourdough LAB. Only Gänzle and Vogel (2003) demonstrated the production of the antibiotic reutericyclin during sourdough fermentation. In situ production of bacteriocin is influenced by growth conditions and by the metabolic state of the bacteriocin-producer (Eckner 1992). Moreover different factors, such as binding of the bacteriocins to food components, inactivation by proteases, changes in solubility and charge of the bacteriocins, as well as changes in the cell envelop of the target micro-organisms, can affect the activity of bacteriocins in foods (Gänzle et al. 1999). In this paper, we provide preliminary data on the in situ bacteriocin production and activity by $L b$. pentosus $2 \mathrm{MF} 8$ and, especially, Lc. lactis M30. We demonstrate that the latter bacteriocinogenic strains can support the implantation of selected starter by inhibiting some of the LAB (e.g. $L b$. plantarum) frequently prevailing during sourdough propagation. Moreover, for the first time the BLIS production by Lb. pentosus isolated from sourdough has been reported. Further studies are warranted to obtain direct evidence for bacteriocin production in sourdough and to evaluate the contribution the bacteriocin-producing strains can give, as 'supporting cultures' to the stable persistence of $L b$. sanfranciscensis during the repeated use of the sourdough. Moreover, with the same approach, other technological useful co-cultures could be selected and tested to produce sourdough with a stable and persistent microflora.

\section{REFERENCES}

Atrih, A., Rekhif, N., Moir, A.J.G., Lebrihi, A. and Lefebvre, G. (2001) Mode of action, purification and amino acid sequence of plantaricin $\mathrm{C19}$, an anti-Listeria bacteriocin produced by 
Lactobacillus plantarum C19. International Journal of Food Microbio$\log y$ 68, 93-104.

Barefoot, S.F. and Klaenhammer, T.R. (1983) Detection and activity of lactacin B, a bacteriocin produced by Lactobacillus acidophilus. Applied and Environmental Microbiology 45, 1808-1815.

Corsetti, A. and Gobbetti, M. (2002) Lactobacillus plantarum. In Encyclopedia of Dairy Sciences, Vol. 3 ed. Roginki, H., Fuquai, J.W. and Fox, P.F. pp. 1501-1507. San Diego, CA: Academic Press Ltd.

Corsetti, A., Gobbetti, M. and Rossi, J. (1994) Sourdough fermentation in presence of added soluble carbohydrates. Microbiologie Aliments Nutrition 12, 377-385.

Corsetti, A., Gobbetti, M. and Smacchi, E. (1996) Antibacterial activity of sourdough lactic acid bacteria: isolation of a bacteriocin-like inhibitory substance from Lactobacillus sanfrancisco C57. Food Microbiology 13, 447-456.

Corsetti, A., Gobbetti, M., Rossi, J., Haznedari, S., Buffa, T. and Rocchetti, G. (1998) Batteri lattici e lieviti da frumento tenero e farine biologiche - Isolamento ed identificazione. Tecnica molitoria 49, 1-8.

Corsetti, A., Gobbetti, M., Rossi, J. and Damiani, P. (1998) Antimould activity of sourdough lactic acid bacteria: identification of a mixture of organic acids produced by Lactobacillus sanfrancisco CB1. Applied Microbiology and Biotechnology 50, 253-256.

Corsetti, A., Lavermicocca, P., Morea, M., Baruzzi, F., Tosti, N. and Gobbetti, M. (2001). Phenotypic and molecular identification and clustering of lactic acid bacteria and yeasts from wheat (species Triticum durum and Triticum aestivum) sourdoughs of Southern Italy. International fournal of Food Microbiology 64, 95-104.

De Los Reyes-Gavilàn, C.G., Limsowtin, G.K.Y., Tailliez, P., Séchaud, L. and Accolas, J.P. (1992) A Lactobacillus helveticusspecific DNA probe detects restriction fragment length polymorphisms. Applied and Environmental Microbiology 58, 3429-3432.

De Man, J.C., Rogosa, H. and Sharpe, M.E. (1960) A medium for the cultivation of lactobacilli. Fournal of Applied Bacteriology 7, $130-135$.

De Vuyst, L. and Vandamme, E.J. (1994a) Antimicrobial potential of lactic acid bacteria. In Bacteriocins of Lactic Acid Bacteria: Microbiology, Genetics and Applications ed. De Vuyst, L. and Vandamme, E.J. pp. 91-142. London: Blackie Academic and Professional.

De Vuyst, L. and Vandamme, E.J. (1994b) Bacteriocins of Lactic Acid Bacteria: Microbiology, Genetics and Applications ed. De Vuyst, L. and Vandamme, E.J. pp. 536. London: Blackie Academic and Professional.

Eckner, K.F. (1992) Bacteriocins and food application. Dairy, Food and Environmental Sanitation 12, 204-209.

Eijsink, V.G.H., Axelsson, L., Diep, D.B., Håvarstein, L.S., Holo, H. and Nes, I.F. (2002). Production of class II bacteriocins by lactic acid bacteria; an example of biological warfare and communication. Antonie van Leeumenhoek 81, 639-654.

Ennahar, S., Aoude-Werner, D., Sorokine, O., van Dorsselaer, A., Bringel, F., Hubert, J.C. and Hasselmann, C. (1996) Production of pediocin AcH by Lactobacillus plantarum WHE 92 isolated from cheese. Applied and Environmental Microbiology 62, 4381-4387.

Foulquié Moreno, M.R., Rea, M.C., Cogan, T.M. and De Vuyst, L. (2003) Applicability of a bacteriocin-producing Enterococcus faecium as a co-culture in Cheddar cheese manufacture. International fournal of Food Microbiology 81, 73-84.
Gänzle, M.G. (1998) Useful properties of lactobacilli for application as protective cultures in food. $P h D$ thesis, University of Hohenheim, Germany. 160 pp.

Gänzle, M.G. and Vogel, R.F. (2003) Contribution of reutericyclin production to the stable persistence of Lactobacillus reuteri in an industrial sourdough fermentation. International fournal of Food Microbiology 80, 31-45.

Gänzle, M.G., Weber, S. and Hammes, W.P. (1999) Effect of ecological factors on the inhibitory spectrum and activity of bacteriocins. International fournal of Food Microbiology 46, 207-217.

Gänzle, M.G., Höltzel, A., Walter, J., Jung, G. and Hammes, W.P. (2000) Characterization of reutericyclin produced by Lactobacillus reuteri LTH2584. Applied and Environmental Microbiology 66, 43254333.

Gobbetti, M. and Corsetti, A. (1997) Lactobacillus sanfrancisco a key sourdough lactic acid bacterium: a review. Food Microbiology 14, 175-187.

Gobbetti, M., Corsetti, A., Rossi, J., La Rosa, F. and De Vincenzi, S. (1994) Identification and clustering of lactic acid bacteria and yeasts from wheat sourdoughs of Central Italy. Italian fournal of Food Science 1, 85-94.

Gobbetti, M., Corsetti, A. and Rossi, J. (1994) The sourdough microflora. Interactions between lactic acid bacteria and yeasts: metabolism of carbohydrates. Applied Microbiology and Biotechnology 41, 456-460.

Gobbetti, M., Corsetti, A. and Rossi, J. (1995) Interactions between lactic acid bacteria and yeasts in sour-dough using a rheofermentometer. World Fournal of Microbiology and Biotechnology 11, 625630 .

Hammes, W.P. and Gänzle, M.G. (1997) Sourdough breads and related products. In Microbiology of Fermented Foods, Vol. 1 ed. Wood, B.J.B. pp. 199-216. London: Blackie Academic and Professional.

Hammes, W.P., Stolz, P. and Gänzle, M.G. (1996) Metabolism of lactobacilli in traditional sourdoughs. Advances in Food Science 18, $176-184$.

Hartnett, D.J., Vaughan, A. and van Sinderen, D. (2002) Antimicrobial-producing lactic acid bacteria isolated from raw barley and sorghum. Fournal of the Institute of Breming 108, 169-177.

Jack, R.W., Tagg, J.R. and Ray, B. (1995) Bacteriocins of Grampositive bacteria. Microbiological Reviems 59, 171-200.

Jiménez-Diaz, R., Ruiz-Barba, J.L., Cathcart, D.P., Holo, H., Nes, I.F., Sletten, K.H. and Warner, P.J. (1995) Purification and partial amino acid sequence of plantaricin $S$, a bacteriocin produced by Lactobacillus plantarum LPCO10, the activity of which depends on the complementary action of two peptides. Applied and Environmental Microbiology 61, 4459-4463.

Klaenhammer, T.R. (1988) Bacteriocins of lactic acid bacteria. Biochimie 70, 337-349.

Klaenhammer, T.R. (1993) Genetics of bacteriocins produced by lactic acid bacteria. FEMS Microbiology Reviews 12, 39-86.

Kline, L. and Sugihara, T.F. (1971) Microorganisms of the San Francisco sour dough bread process. II. Isolation and characterization of undescribed bacterial species responsible for the souring activity. Applied Microbiology 21, 459-465.

Larsen, A.G., Vogensen, F.K. and Josephsen, J. (1993) Antimicrobial activity of lactic acid bacteria isolated from sour doughs: purification 
and characterization of bavaricin A, a bacteriocin produced by Lactobacillus bavaricus MI401. Fournal of Applied Bacteriology 75, 113-122.

Lavermicocca, P., Valerio, F., Evidente, A., Lazzaroni, S., Corsetti, A. and Gobbetti, M. (2000) Purification and characterization of novel antifungal compounds by sourdough Lactobacillus plantarum 21B. Applied and Environmental Microbiology 66, 4084-4090.

Leroy, F. and De Vuyst, L. (2000) Sakacins. In Natural Food Antimicrobial Systems ed. Naidu, A.S. pp. 589-610. London: CRC Press.

Lewus, C.B., Sun, S. and Montville, T.J. (1992) Production of an $\alpha$-amylase-sensitive bacteriocin by an atypical Leuconostoc paramesenteroides strain. Applied and Environmental Microbiology 58, 143-149.

Messens, W. and De Vuyst, L. (2002) Inhibitory substances produced by Lactobacilli isolated from sourdoughs - a review. International Journal of Food Microbiology 72, 31-43.

Messens, W., Neysens, P., Vansieleghem, W., Vanderhoeven, J. and De Vuyst, L. (2002) Modeling growth and bacteriocin production by Lactobacillus amylovorus DCE 471 in response to temperature and $\mathrm{pH}$ values used for sourdough fermentations. Applied and Environmental Microbiology 68, 1431-1435.

Navarro, L., Zarazaga, M., Sáenz, J., Ruiz-Larrea, F. and Torres, C. (2000) Bacteriocin production by lactic acid bacteria isolated from Rioja red wines. Fournal of Applied Microbiology 88, 44-51.

Nes, I.F., Diep, B.D., Håvarstein, L.S., Brurberg, M.B., Eijsink, V. and Holo, H. (1996) Biosynthesis of bacteriocins in lactic acid bacteria. Antonie van Leeumenhoek 70, 113-128.

Rasch, M. and Knochel, S. (1998). Variations in tolerance of Listeria monocytogenes to nisin, pediocin PA-1 and bavaricin A. Letters in Applied Microbiology 27, 275-278.

Röcken, W. and Spicher, G. (1993) Fadenziehende Bakterien-Vorkommen, Bedeutung, Gegenmaßnahmen. Getreide Mehl Brot 47, 30-35.

Rodríguez, E., Gonzáles, B., Gaya, P., Nuñez, M. and Medina, M. (2000) Diversity of bacteriocins produced by lactic acid bacteria isolated from raw milk. International Dairy fournal 10, 7-15.
Rosenkvist, H. and Hansen, A. (1995) Contamination profiles and characterization of Bacillus species in bred and raw material for bread production. International Fournal of Food Microbiology 26, 353-363.

Rosenquist, H. and Hansen, A. (1998) The antimicrobial effect of organic acids, sour dough and nisin against Bacillus subtilis and B. licheniformis isolated from wheat bread. Fournal of Applied Microbiology 85, 621-631.

Schillinger, U. and Holzapfel, W.H. (1996) Guidelines for manuscripts on bacteriocins of lactic acid bacteria. International Fournal of Food Microbiology 33, 3-5.

Schillinger, U. and Lücke, F.K. (1989) Antibacterial activity of Lactobacillus sake isolated from meat. Applied and Environmental Microbiology 55, 1901-1906.

Suma, K., Misra, M.C. and Varadaraj, M.C. (1998) Plantaricin LP84, a broad spectrum heat-stable bacteriocin of Lactobacillus plantarum NCIM 2084 produced in a simple glucose broth medium. International Fournal of Food Microbiology 40, 17-25.

Tagg, J.R., Dajani, A.S. and Wannamaker, L.W. (1976) Bacteriocins of Gram-positive bacteria. Bacteriological Reviems 40, 722-756.

Todorov, S., Onno, B., Sorokine, O., Chobert, J.M., Ivanova, I. and Dousset, X. (1999) Detection and characterization of a novel antibacterial substance produced by Lactobacillus plantarum ST 31 isolated from sourdough. International fournal of Food Microbiology 48, 167-177.

Upreti, G.C. and Hinsdill, R.D. (1975) Production and mode of action of lactocin 27: bacteriocin from homofermentative Lactobacillus. Antimicrobial Agents and Chemotherapy 7, 139-145.

Vaughan, A., Eijsink, V.G.H., O'Sullivan, T.F., O’Hanlon, K. and van Sinderen, D. (2001) An analysis of bacteriocins produced by lactic acid bacteria isolated from malted barley. Fournal of Applied Microbiology 91, 131-138.

Yang, R., Johnson, M.C. and Ray, B. (1992) Novel method to extract large amounts of bacteriocins from lactic acid bacteria. Applied and Environmental Microbiology 58, 3355-3359. 